\title{
Natural history of child food allergies - Analyzing the time factor
}

\author{
Istoria naturală a alergii lor alimentare la copil - analizând factorul timp
}

$\begin{array}{r}\text { Mirela Ionela Stocklosa', Raluca Maria Vlad²,3, Coriolan Ulmeanu²,3 } \\ \text { 'Spitalul Clinic „Ion Cantacuzino“, Bucureşti, România } \\ \text { ²Clinica Pediatrie 3, Spitalul de Urgenţă pentru Copii „Grigore Alexandrescu“, Bucureşti, România } \\ \text { 'Universitatea de Medicină şi Farmacie „Carol Davila“, Bucureşti, România } \\ \hline\end{array}$

\begin{abstract}
Food allergy is a hot topic, considering the rise in incidence the allergic disease exhibits in children. Nevertheless, the recent medical literature does not cover the natural history and evolution particularities of this disease. The first atopic diseases are food allergies and atopic dermatitis, followed by astma and allergic rhinitis. The most frequent food allergies are cow's milk protein, egg, wheat, soy, peanut and fish. The sever-ity of symptoms on the onset of cow's milk protein allergy is predictive for a negative impact on length of the disease. Egg allergy is a predictive factor for astma. Peanut and fish allergies may be persistent into adult-hood. Food allergy is polimorphic, the diagnosis takes time and the course of the disease is different for dif-ferent allergens and clinical forms.
\end{abstract}

Keywords: food allergy, tolerance

\section{REZUMAT}

Alergia alimentară este un subiect de mare actualitate în contextul creşterii semnificative a incidenţei botilor alergice la copil. În literatura ultimilor ani lipsesc însă date recente despre istoria naturală şi particularităţile de evoluţie. Primele manifestări ale atopiei sunt alergiile alimentare şi dermatita atopică, urmând astmul bronşic şi rinita alergică. Cele mai frecvente alergii alimentare sunt la proteinele laptelui de vacă, ou, grâu, soia, alune şi peşte. Severitatea simptomelor la debutul alergiei la proteinele din laptele de vacă este considerată factor de prognostic negativ pentru durata bolii. Alergia alimentară la ou reprezintă un factor predictiv pentru dezvoltarea astmului bronşic. Alergiile alimentare la alune şi la peşte sunt forme de alergie persistentă în perioada de adult. Alergia alimentară este o patologie polimorfă, diagnosticul este de durată şi evoluţia variabilă în timp în funç̧ie de alergenul incriminat şi forma de manifestare a bolii.

Cuvinte cheie: alergie alimentară, toleranţă

\section{INTRODUCERE}

Alergia alimentară debutează cel mai frecvent în copilărie. Primele manifestări ale atopiei sunt alergiile alimentare şi dermatita atopică, urmând, odată cu creşterea în vârstă, să fie înlocuite de astmul bronşic şi rinita alergică (,marşul alergic“) $(1,2)$. Astfel, un copil cu teren atopic este candidat pentru una sau mai multe afecţiuni alergice.

Evoluţia naturală a alergiilor alimentare nu este bine cunoscută deoarece rezultatele studiilor actuale sunt diferite (în funcţie de designul studiului). Majoritatea alergiilor alimentare sunt dobândite în primii doi ani de viaţă (3). Cele mai frecvente aler- gii alimentare sunt la proteinele laptelui de vacă, ou, grâu, soia, alune şi peşte. În general, alergia la proteinele laptelui de vacă, ou, grâu şi soia dispar odată cu înaintarea în vârstă. Totuşi, alergia alimentară la alune, peşte şi crustacee tinde să persiste toată viaţa (4).

\section{Alergia la proteinele din laptele de vacă}

Alergia la proteinele din laptele de vacă este, de obicei, prima manifestare a marşului alergic (5). Simptomele acestei alergii sunt observate frecvent din primele două luni de viaţă (6-8).

Intervalul de timp până la dobândirea toleranţei imunologice este variabil. În primele studii de co- 
hortă, alergia la proteinele din laptele de vacă durează în medie 1 an (9). Într-un studiu realizat în Italia, în care s-a folosit testul de provocare dubluorb-placebo controlat pentru diagnosticul alergiei la proteinele din laptele de vacă, durata medie a acestei afecţiuni a fost de 23 de luni (10). În studiile mai recente, se observă că doar în $80 \%$ dintre cazuri se obţine o toleranţă imunologică la proteinele din laptele de vacă la vârsta de 3-4 ani (10-12).

Evoluţia alergiei la proteinele din laptele de vacă a fost studiată în funcţie de tipul reacţiei clinice la debut (imediată sau tardivă), cât şi din punct de vedere al influenţei mecanismului fiziopatologic ( $\operatorname{IgE}$ mediat sau non IgE mediat). Astfel, într-un studiu finlandez, s-a observat că, în cazul copiilor cu reacţii întârziate, alergia alimentară s-a remis mai devreme decât în cazul celor cu reacţii imediate $(64 \%, 92 \%$ şi $96 \%$ faţă de $31 \%, 53 \%$ şi $63 \%$ la 2 , 3 şi 4 ani) (13). Copiii cu alergie alimentară nonIgE mediată au obţinut toleranţă imunologică mai devreme decât cei cu alergii IgE mediată, la o vârsta medie de 5 ani (13-15). În cadrul studiului EuroPrevall, copiii cu alergie la proteinele din laptele de vacă non- $\operatorname{IgE}$ mediate au dobândit toleranţă imunologică după 1 an (16).

În cazul copiiilor cu alergii alimentare care asociază simptome respiratorii, durata afecţiunii alergice este mai îndelungată (10).

O preocupare deosebită a studiilor a fost aceea de a identifica factori de prognostic pentru evoluţia alergiei la proteinele din laptele de vacă. Istoricul familial pozitiv pentru boli alergice (astm bronşic, rinită alergică, dermatită atopică) reprezintă un factor de prognostic pentru o evoluţie de durată a afecţiunii alergice (17). De fapt, numai prezenţa astmului bronşic, rinitei alergice sau dermatitei atopice în antecedentele heredo-colaterale reprezintă un factor de prognostic mult mai important decât prezenţa alergiei alimentare în antecedentele familiale (18). Existenţa în familie a mai mult de doi membri cu alergii a fost puternic predictivă pentru dezvoltarea alergiei alimentare la copil (18).

Severitatea simptomelor la debutul alergiei la proteinele din laptele de vacă este considerată factor de prognostic negativ pentru durata bolii $(5,10)$. Asocierea simptomelor respiratorii la debutul alergiei cu simptome cutanate şi/sau digestive este considerată factor de risc pentru persistenţa îndelungată şi rezoluţia mai lentă a alergiei la proteinele din laptele de vacă $(10,19)$.

Diametrul reacţiei cutanate crescut la testele prick cu lapte proaspăt a fost semnificativ corelată cu eşecul dobândirii toleranţei imunologice (10). Toţi pacienţii cu alergie la proteinele din laptele de vacă şi teste cutanate prick negative la vârsta de 1 an au dezvoltat toleranţă imunologică la aceste proteine până la vârsta de 3 ani.

Scăderea titrurilor anticorpilor IgE specifici sunt factori de prognostic pentru dezvoltarea toleranţei imunologice $(13,19)$. O scădere cu $99 \%$ a anticorpilor IgE anti-proteină din laptele de vacă mai mult de 12 luni se corelează cu o probabilitate de $94 \%$ de dobândire a toleranţei imunologice la proteinele din laptele de vacă (19). Subtipurile de anticorpi IgE anti-proteina laptelui de vacă au fost studiaţi. Prezenţa anticorpilor anticazeină au fost asociaţi cu formele persistente de alergie la proteinele din laptele de vacă $(10,20)$.

În studiul său, Wood a arătat că $70 \%$ dintre pacienţii cu $\operatorname{IgE}$ antiproteină lapte vacă pozitiv dar $<2 \mathrm{kUA} / 1$ au dobândit toleranţă imunologică faţă de $23 \%$ dintre pacienţi cu IgE antiproteină lapte vacă $>10 \mathrm{kUA} / \mathrm{l}(21)$.

Sensibilizările simultane decelate prin teste cutanate sau teste serologice, în special la carnea de vacă, ouă, grâu şi soia, sunt factori de prognostic negativ pentru alergia la proteinele din laptele de vacă (10).

\section{Alergia la ou}

În studiile realizate în Suedia (22) şi Spania (23) s-a evidenţiat că majoritatea copiilor cu alergie la ou devin toleranţi la o vârstă fragedă. Aproximativ $66 \%$ dintre copiii incluşi în studiu au devenit toleranţi la ou la vârsta de 7 ani.

În studiile din SUA, proporţia cazurilor de rezoluţie a alergiei alimentare la ou a fost mult mai mică: 26\% au dobândit toleranţă imună la vârsta de 6 ani, iar la 10 ani doar 53\% dintre copii nu mai prezentau această alergie (24). Factori de prognostic pentru persistenţa alergiei alimentare la ou evidenţiaţi în acest studiu sunt reprezentaţi de titrurile iniţiale crescute ale anticorpilor IgE specifici, prezenţa unei alte boli atopice şi existenţa mai multor alergii alimentare.

Severitatea simptomatologiei iniţiale nu se corelează cu evoluţia bolii (25). Totuşi, existenţa manifestărilor respiratorii în cadrul alergiei alimentare la ou se corelează mai frecvent cu formele persistente $(23,26)$.

Există o asociere între rezultatele testelor cutanate prick, titrurile anticorpilor IgE specifici şi evoluţia clinică a alergiei. Reducerea titrurilor anticorpilor IgE specifici reprezintă un marker de evoluţie favorabilă (4). În studiul lui Boyano-Martinez, copiii care işi redobândeau toleranţă imună la ou prezentau diametrul papulei la testul cutanat prick $<6 \mathrm{~mm}(23)$. 
Alergia alimentară la ou reprezintă un factor predictiv pentru dezvoltarea astmului bronşic, a altor alergii alimentare şi a sensibilizărilor respiratorii ulterioare $(27,28) .46 \%$ dintre copiii sensibilizaţi la ou vor fi sensibilizaţi la mucegai până la vârsta de 3 ani. $40 \%$ dintre aceştia vor dezvolta astm bronşic până la vârsta de 5 ani. La adulţi, astmul bronşic este de 10 ori mai frecvent la cei care au avut teste cutanate pozitive la ou, lapte sau amândouă la 3 luni, 6 luni sau 2 ani, comparativ cu cei fără sensibilizări dovedite prin teste cutanate sau serologice.

\section{Alergia la alune}

Alergia alimentară la alune este o formă de alergie persistentă deoarece nu se ameliorează odată cu trecerea la viaţa de adult. Studiile din SUA au evidenţiat că doar $20 \%$ dintre copii redobândesc toleranţa imună la alune (29-33). Totodată, în cazul acestei alergii, există un risc de aproximativ $4 \%$ de recurenţă a afecţiunii după remisia iniţială (32).

\section{Alergia la grâu}

Alergia alimentară la grâu este o formă de alergie care se remite odată cu creşterea. Aproximativ $65 \%$ dintre copiii cu această alergie işi redobândesc toleranţa imună la varsta de 12 ani. O mică proporţie vor prezenta această alergie şi în perioada de adolescenţă (34).

\section{Alergia la soia}

Copiii care au alergie la proteinele din laptele de vacă pot avea alergie şi la soia în proporţie de

\section{BIBLIOGRAFIE}

1. Illi S, von Mutius E, Lau S, Nickel R, Niggemann B, Sommerfeld C, Wahn U- Multicenter Allergy Study Group. The pattern of atopic sensitization is associated with the development of asthma in childhood. J Allergy Clin. Immunol., 2001, 108, 709-14

2. Illi S, von Mutius E, Lau S, Nickel R, Gruber C, Niggemann B, Wahn U- Multicenter Allergy Study Group. The natural course of atopic dermatitis from birth to age 7 yaers and the association with asthma. J Allergy Clin. Immunol., 2004, 113, 925-31

3. Wood RA. The natural history of food allergy. Pediatrics, 2003, 111, 1631-7

4. Sampson HA- Update on food allergy. J Allergy Clin. Immunol., 2004, $113,805-19$

5. World Allergy Organisation (WAO) Diagnosis and Rationale for Action against Cow's Milk Allergy (DRACMA) guidelines. WAO Journal 2010

6. De Boissieu D, Mantarazzo P, Rocchiccioli F, Dupont C. Multiple food allergy: A possible diagnosis in breastfed infants. Acta Pediatr 1997; 86, 1042-1046

7. Jarvinen K-M, Makinen-Kiljunen S, Suomalainen H. Cow's milk challenge via human milk evokes immune responses in suckling infants with cow's milk allergy. J Pediatr 1999; 135, 506-512

8. Jarvinen K-M, Suomalainen H. Development of cow's milk allergy in breastfed infants. Clinical and Experimental Allergy, 2001, 31, 978-987
$8-14 \%$ dintre cazuri (35). Într-un studiu retrospectiv, toleranţa la soia s-a obţinut în proporţie de $50 \%$ la vârsta de 7 ani şi $69 \%$ la vârsta de 10 ani (36).

\section{Alergia la peşte şi crustacee}

Această formă de alergie alimentară persistă pe tot parcursul vieţii (37), recomandându-se dieta de excludere strictă, inclusiv evitarea contactului cu pielea sau căile respiratorii (38).

În diverse studii s-a demonstrat existenţa unei reacţii încrucişate între crustacee şi praful de casă, ceea ce este important în managmentul acestor alergii $(39,40)$.

\section{CONCLUZII}

Alergia alimentară este un subiect de mare actualitate în contextul creşterii semnificative a incidenţei bolilor alergice la copil. Literatura ultimilor ani se axează însă în principal pe metode moderne de diagnostic şi tratament, lipsind date recente despre istoria naturală şi particularităţile de evoluţie. Este vorba despre o patologie polimorfă, diagnosticul este de durată şi persistenţa simptomatologiei variabilă în timp în funcţie de alergenul incriminat şi forma de manifestare a bolii. $\mathrm{Cu}$ puţine excepţii, toleranţa este dobândită în primii ani de viaţă în procente importante.
9. Host A. Cow's milk protein allergy and intolerance in infancy. Some clinical, epidemiological and immunological aspects. Pediatr Allergy Immunol 1994; 5:1-136

10. Fiocchi A, Terracciano L, Bouygue GR, Veglia F, Sarratud T, Martelli A, Restani P. Incremental prognostic factors associated with cow's milk allergy outcomes in infant and child referrals: the Milan Cow's Milk Allergy Cohort Study. Ann Allergy Asthma Immunol.2008; 101, 166-173

11. Hill DJ, Firer MA, Ball G, Hosking CS. Natural history of cow's milk allergy in children: Immunological outcome over 2 years. Clin Exp Allergy 1993; 23, 124-131

12. Garcia-Ara MC, Boyano-Martinez MT, Diaz-Pena JM, Martin-Munoz MF, Martin-Esteban M. Cow's milk-specific immunoglobulin E levels as predictors of clinical reactivity in the follow-up of the cow's milk allergy infants. Clin Exp Allergy 2004; 34, 866-870

13. Vanto T, Helppila S, Juntunen-Backman $\mathrm{K}$ et al. Prediction of the development of tolerance to milk in children with cow milk hypersensitivity. J Pediatr. 2004; 144, 218-222

14. Host A, Halken S, Jacobsen HP, Chiristensen AE, Herskind AM, Plesner K. Clinical course of cow's milk protein allergy/intolerance and atopic diseases in childhood. Pediatr Allergy Immunol 2002; 3; 23-28

15. Saarinen KM, Pelkonen AS, Makela MJ, Savilahti E. Clinical course and prognosis of cow's milk allergy are dependent on milk-specific lgE status. J Allergy Clin Immunol 2005. 116; 869-875 
16. Schoemaker AA, Sprikkelman AB, Grimshaw KE, Roberts $\mathrm{G}$ et al. Incidence and natural history of challenge-proven cow's milk allergy in European children- EuroPrevall bith cohort. Allergy 2015; 70, 963-72

17. Notarbarttolo A, Carroccio A. Persistent cow's milk protein intolerance in infants: the changing faces of the same disease. Clin Exp Allergy 1998; 28; 817-823

18. Koplin J, Allen K, Gurrin L.C, Peters R.L, Lowe A.J, Tang, M, Dharmage S, HealthNuts Study Team. The impact of family history allergy on risk of food allergy: a population-based study on infants. Int J. Environ. Res. Public Health 2013, 10, 5364-5377

19. Shek LP, Soderstrom L, Ahlstedt S, Beyer K, Sampson HA. Determination of food specific lgE levels over time can predict the development of tolerance in cow's milk and hen's egg allergy. $J$ Allergy Clin Immunol 2004; 114; 387-391

20. Skripak JM, Matsui EC, Mudd K, Wood RA. The natural history of IgE-mediated cow's milk allergy. J Allergy Clin Immunol 2007; 120; 1172-1177

21. Wood RA, Sicherer S, Vickery B, Jones S, Liu A, Fleischer D, Henning A, Mayer L, Burks W, Grishin A, Sampson H. The natural history of milk allergy in an observational cohort. J Allergy Clin Immunol 2013; 131, 805-812

22. Hattevig G, Kjelmann B, Bjorksten B. Clinical symtoms and IgE responses to common food proteins and inhalants in the first 7 years of life. Clin Allergy 1987; 17, 571-578

23. Boyano-Martinez T, Garcia-Ara C, Diaz-Pena JM, Martin-Esteban M. Prediction of tolerance on the basis of quantification of egg white-specific IgE antibodies in children with egg allergy.J Allergy Clin Immunol 2002; 10; 304-309

24. Savage JH, Matsui EC, Skripak JM, Wood RA. The natural history of egg allergy. J Allergy Clin Immunol 2007; 120; 1413-1417

25. Spergel JM, Beausoleil JL, Fiedler JM, Ginsberg J, Wagner K, Pawloswki NA. Correlation of initial food reactions to observed reactions on challenges. Ann Allerrgy Asthma Immunol 2004; 92, 217-24

26. Osterballe M, Bindslev-Jensen C. Threshold levels in food challenge and specific $\lg E$ in patients with egg allergy: Is there a relationship? J Allergy Clin Immunol 2003; 112, 196-201

27. Tariq SM, Matthews SM, Hakim EA, Arshad SH. Egg allergy in infancy predicts respiratory allergic disease by 4 tears of age. Pediatr Allergy Immunol 2000; 11, 162-7
28. Rhodes HL, Sporik R, Thomas P, Holgate ST, Cogswell JJ. Early life risk factors for adult asthma: a birth cohort study of subjects at risk. J Allergy Clin Immunol 2001; 108, 720-5

29. Skolnick HS, Conover-Walker MK, Koerner CB, Sampson HA, Burks W, Wood RA. The natural history of peanut allergy. J Allergy Clin Immunol 2001; 107, 367-74

30. Vander Leek TK, Liu AH, Stefanski K, Blacker B, Bock SA. The natural history of peanut allergy in young children and its association with serum peanut- specific IgE. J Pediatr 2000; 137, 749-55

31. Green TD, LaBelle VS, Steele PH, Kim EH, Lee LA, Mankad VS. Clinical characteristics of peanut-allergic children: recent changes. Pediatrics 2007; 120, 1304-10

32. Fleischer DM, Conover-Walker MK, Christie L, Burks AW, Wood RA. Peanut allergy: recurrence and its management. J Allergy Clin Immunol 2004; 114, 1195-201

33. Savage JH, Limb SL, Brereyton NH, Wood RA. The natural history of peanut allergy: Extending our knowledge beyond childhood. J Allergy Clin Immunol 2007; 120, 717-9

34. Keet CA, Matsui EC, Dhillon G, Lenehan P, Paterakis M, Wood RA. The natural history of wheat allergy. Ann Allergy Asthma Immunol 2009; 102, 410-5

35. Zeiger RS, Sampson HA, Bock SA, Burks AW, Harden K, Noone S, Martin D, Leung S, Wilson G. Soy allergy in infant and children with IgE-associated cow's milk allergy. J Pediatr 1999; 134, 614-22

36. Savage JH, Kaeding AJ, Matsui EC, Wood RA. The natural history of soy allergy. J Allergy Clin Immunol 2010; 125, 683-6

37. Sicherer SH, Munoz-Furlong, Sampson HA. Prevalence of seafood allergy in United States determined by a random telephone survey. J Allergy Clin Immunol 2004; 114, 159-65

38. Roberts G, Lack G. Relevance of inhalational exposure to food allergens. Cur Opin. Allergy Clin Immunol 2003; 3, 211-5

39. Pajno GB, Morabito L, Barberio G. Allergy to house dust mite and snails: A model of cross-reaction between food and inhalant allergens with a clinical impact. Pediatr Pulmonol 1999; 18, 163-4

40. Azofra J, Lombardero M. Limpet anaphylaxis: Cross-reactivity between limpet and house-dust mite Dermatophagoides pteronyssinus. Allergy 2003; 58, 146-9. 